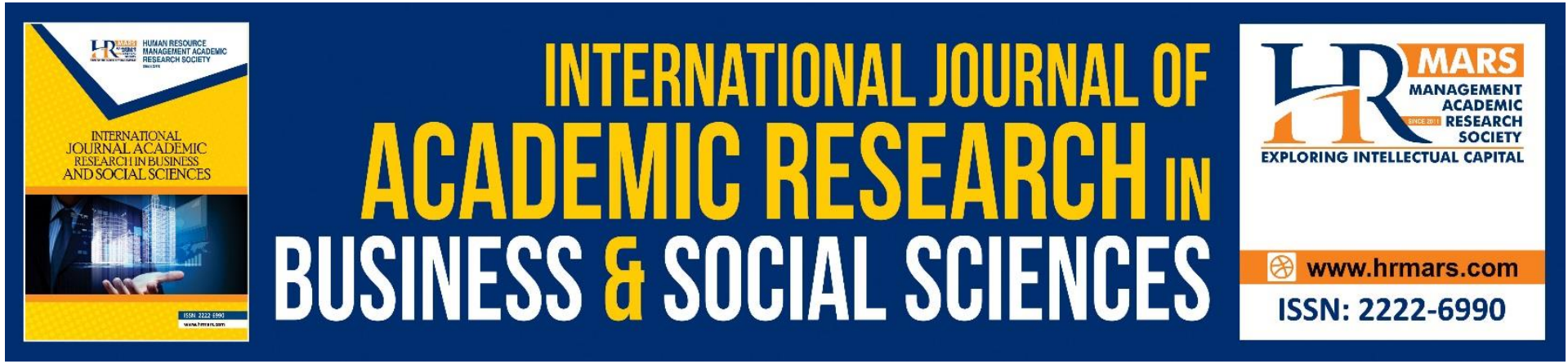

\title{
Brand Awareness of Private University College, Melaka (PUCM)
}

Maryam Mohd Esa, Noorizda Emellia Mohd Aziz, Farah Saniah Mohd Zabidi, Nor Hazanah Miskan \& Zamry Gafar

To Link this Article: http://dx.doi.org/10.6007/IJARBSS/v11-i8/10693 DOI:10.6007/IJARBSS/v11-i8/10693

Received: 08 June 2021, Revised: 16 July 2021, Accepted: 01 August 2021

Published Online: 24 August 2021

In-Text Citation: (Esa et al., 2021)

To Cite this Article: Esa, M. M., Aziz, N. E. M., Zabidi, F. S. M., Miskan, N. H., \& Gafar, Z. (2021). Brand Awareness of Private University College, Melaka (PUCM). International Journal of Academic Research in Business and Social Sciences, 11(8), 1275-1286.

Copyright: (c) 2021 The Author(s)

Published by Human Resource Management Academic Research Society (www.hrmars.com)

This article is published under the Creative Commons Attribution (CC BY 4.0) license. Anyone may reproduce, distribute, translate and create derivative works of this article (for both commercial and non-commercial purposes), subject to full attribution to the original publication and authors. The full terms of this license may be seen at: http://creativecommons.org/licences/by/4.0/legalcode

Vol. 11, No. 8, 2021, Pg. 1275 - 1286

Full Terms \& Conditions of access and use can be found at http://hrmars.com/index.php/pages/detail/publication-ethics 


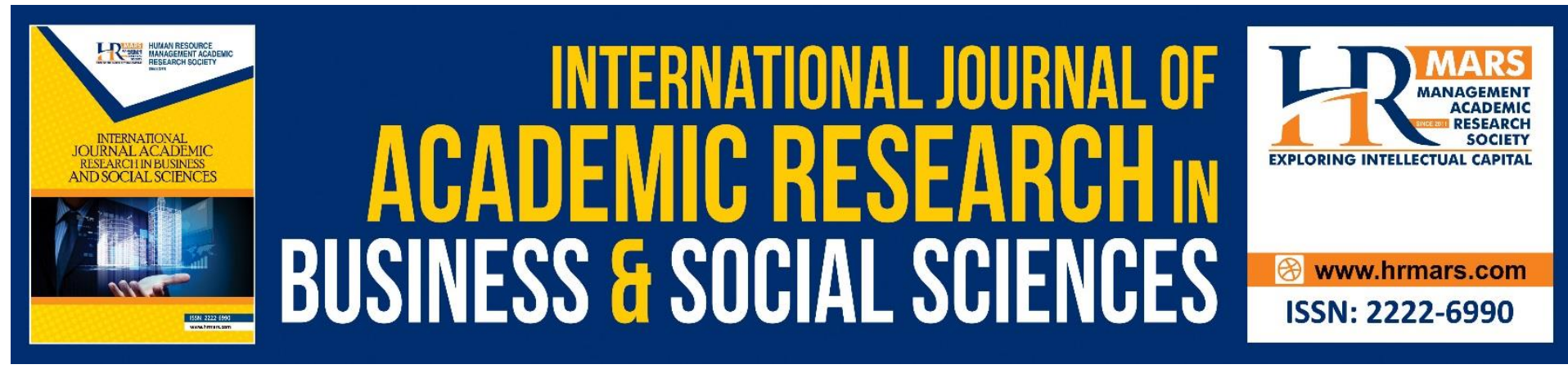

\title{
Brand Awareness of Private University College, Melaka (PUCM)
}

\author{
Maryam Mohd Esa, Noorizda Emellia Mohd Aziz, Farah Saniah \\ Mohd Zabidi, Nor Hazanah Miskan \& Zamry Gafar \\ Faculty of Innovation \& Technology, Kolej Universiti Islam Melaka, Malaysia
}

\begin{abstract}
Background: In the research field of Private University College, Melaka and from the viewpoint of Melaka residents, brand awareness plays a crucial role in their development.

Objectives: This paper identifies the impact of brand awareness, namely brand recognition, brand recall, Top of Mind Awareness; TOMA and brand knowledge.

Method: Using an online survey, the study collects data in Melaka from 300 respondents among residents in Melaka. We used the Statistical Package for the Social Sciences (SPSS) to test the links between dependent variable and independent variables.

Result: The results analyzed by correlation show that: (1) brand recognition has a significant positive influence on brand awareness; (2) brand recall has a significant positive influence on brand awareness; (3) Top of mind awareness (TOMA) has a significant positive influence on brand awareness; (4) brand knowledge has a significant positive influence on brand awareness.

Conclusion: From these elements we identified that brand recognition and brand recall were the most influences towards PUCM brand awareness. In the future research, researchers include all elements of brand awareness which is brand dominance and brand opinion will provide more valid research outcome.
\end{abstract}

Keywords: Brand Awareness, Brand Recognition, Brand Recall, Top of Mind Awareness, Brand Knowledge.

\section{Introduction}

In the education sector, many Higher Education Institutions (HEl's) take initiatives to actively support the government through the facilitation of educational programs. Therefore, there are various HEls that have emerged to enliven the country's education industry. But to what extent is the IPT brand able to survive and give an impact in further increasing the number of students entering their respective IPTs. Brand is an important thing that needs to be emphasized. Through the brand of an IPT, especially PUCM, it is like having an identity that needs to be nurtured and promoted. Product brands can damage the image either because of a bad (negative) experience or because of positive new information about a replacement product. At the same time brand awareness makes customers loyal to the product regardless of price. This study aims to identify the importance of PUCM brand awareness among the residents of Melaka. Various studies agree that brand awareness is an important thing to 
study because it is able to influence the intention to buy. Next the brand itself is able to influence the choice of the consumer. Previous research agrees that brand awareness is important because without brand awareness then no communication and no transaction will take place (Malik et al., 2013). This research was also carried out on the PUCM brand to study the problems faced by IPTs, especially PUCM, which has faced the problem of declining student enrolment in recent years. Thus, the element of brand awareness can be understood more clearly to enhance the strengthening of the PUCM brand and further increase the number of student admissions. Referring to Kotler (2000) defining a brand is the name associated with one or more items in a product line used to identify the source character of an item. The definition from the American Marketing Association (AMA) says that a brand includes a name, term, mark, symbol, or design, or a combination of them, intended to identify goods and services from one vendor or group of vendors and to distinguish them from competitors.

According to Chen (2019) the intense competition among universities has stimulated demand for institutional understanding, institutional management and strong brand utilization. To universities, academic institutions differ from businesses in that they are non-profit organizations. Thus, their management differs from that of businesses, which emphasizes ensuring favorable corporate reputation. Universities regard brands as symbols, which are key communication tools between a business and its customers; brands also strongly influence their customers' purchase decisions. Businesses use their reputations to convey their values to customers, whereas universities use their brand reputation to shape the student perceptions of the school (Chen \& Tsai, 2016).

Thus, this research has come up with five (5) main objectives:

i. To identify the relationship between brand recognition and PUCM brand awareness among the people in the state of Melaka.

ii. To identify the relationship between brand recall and PUCM brand awareness among the people in the state of Melaka.

iii. Identify the relationship between Top-of-Mind Awareness; TOMA with the awareness of the PUCM brand among the people in the state of Melaka.

iv. To identify the relationship between brand knowledge and PUCM brand awareness among the people in the state of Melaka.

v. Identify the importance of key elements on brand awareness that most influence the choice of the people in the state of Melaka in choosing the PUCM brand.

\section{Hypothesis}

$\mathrm{H} 1$ : Brand recognition has a relationship with PUCM brand awareness among the residents in the state of Melaka.

$\mathrm{H} 2$ : Brand recall has a relationship with PUCM brand awareness among the residents in the state of Melaka.

H3: Top of Mind Awareness; TOMA has a relationship with PUCM brand awareness among the residents in the state of Melaka.

$\mathrm{H} 4$ : Brand knowledge has a relationship with PUCM brand awareness among the residents in the state of Melaka. 


\section{Problem Statement}

Various studies agree that brand awareness is an important thing to study because it is able to influence the intention to buy. Next the brand itself is able to influence the choice of the consumer. This research is also carried out to study the problems faced by HEls, especially PUCM, which has faced the problem of declining student enrolment in recent years. Thus, the element of brand awareness can be understood more clearly to enhance the strengthening of the PUCM brand and further increase the number of student admissions. This researcher Noorlitaria et al., (2020) stated that brand name is the most important element in brand awareness and brand awareness will affect purchase decisions through brand associations, and when the product has positive branding, it will contribute in marketing activities. In Malaysia, according to the statistics from Higher Education Institution (HEIs) (2021), there are $435 \mathrm{HEls}$, whereas University (51), International Branch of University Campus (10), University College (39) and College (335). So, it's very important to HEls in Malaysia to develop stable brand awareness among the communities to boost up the number of enrolment students in every intake. All 39 University Colleges need to compete with others in order to have a big number of enrolments. Saying that, brand awareness can be self-checking to HEls in order to evaluate their awareness among the communities.

\section{Brand Awareness}

The awareness of the brand concerns how consumers connect with the specific product they want to receive (Zia et al., 2021). Brand awareness is essential or critical to the process of interaction (communicating with others), i.e., a high level of understanding (Netemeyer et al., 2004). In addition, based on Permana (2021) it mentioned that brand awareness is the ability of the customer to remember or identify a brand. llyas et al (2020) mentioned that brand awareness has several levels starting from the lowest level, namely, not recognizing the brand and brand recognition, the top-of-the-mind recalling stage. Brand awareness can signify the existence, commitment, and core that are very important for a company. So, if the brand's knowledge is high, then the presence of the brand can always be felt. Therefore, several approaches need to be considered to ensure that brand awareness is high and is always a brand choice. Several factors usually cause a brand to gain high brand awareness: advertised continuously, and associated with the existence and distribution of products that reach various groups (Mashur et al., 2019). Brand awareness is measured in different ways in which consumers remember the brand, which may include brand recognition, brand recall, top of mind awareness and brand knowledge.

Brand Recognition

Chun et al (2020) stated that brand recognition has a significant positive effect on brand familiarity and it was found that brand recognition and brand familiarity have a significant positive effect on purchase intention. Brand recognition is the ability of potential customers to recall a brand in a particular product group (brand awareness) or to immediately withdraw certain brand information kept in their memories (brand recall) (Aaker, 2004). Keller (2001) argued that brand recognition is a concept of the ability to distinguish a particular brand among different brands, and consists of four stages: the lowest level of non-recognition, brand awareness, brand recall, and initial recall. Brand recognition acts as an association of product images, increases familiarity and favorability with products, gives trust to products and companies, and includes specific products in purchase considerations. Therefore, brand recognition is linked to familiarity and affinity with products and businesses, which develops into trust in the company and products and services, giving a positive effect on purchasing 
behavior (Aaker, 2004). It was observed that brand recognition has a positive effect on purchase intention (Ilyas et al., 2020).

Brand Recall

Brand awareness comprises two factors - brand recall and brand recognition. If the buying intention of a consumer is evaluated as a two-dimensional quantity, brand recognition represents the depth and brand recall represents the breadth of the buyer paradigm (Havale $\&$ Chaudhari, 2020). The brand image reflects automatic impact on how the customers are relating themselves with the brand, which ideally should be strong (consistency and relevance), favorable (deliverability and desirability), and unique (exceptional and sophisticated) (Keller, 2008). Many researchers have measured the effectiveness of brand placements in relation to how well they were recalled (Gupta, 1998). In the modern world, customers rely heavily on the ability to recall when making purchasing decisions due to lack of time to recall other marketing efforts (e.g., advertisements on television, etc.) from marketers (Prashar et al., 2012). Consumers are able to recall a brand while making a purchase decision, it is called brand recall (Huang \& Sarigöllü, 2012). Similarly, consumers choose to purchase the brand, which illustrates higher recall due to event sponsorship (Biscaia, Correia, Ross \& Rosado, 2014). Consumers with high brand recall are more likely to buy the brand (Ndlela \& Chuchu, 2016). The previous researcher, Schmidt \& Eisend (2015) through their article say that in order to get your brand in mind; Remember. For the brand recall effect, more levels of exposure are required. Advertising needs to be strengthened and mass exposure increases the impact of repetition on brand recall.

Top of Mind Awareness; TOMA

Top of mind awareness or called TOMA, in general is about the brand that obviously comes to mind first when an unprompted question about a category is asked to a customer and it relates to the percentage of customers who think of a particular brand first. According to Gijsenberg \& Nijs (2019) across a wide range of real-world scenarios, investing in top-of-mind awareness through maintenance advertising insulates brands from competitors' actions and boosts sales. Besides, having a relevant operationalization of brand awareness needs to account for the history of the brand. It automatically determines how well brands rank in the mind of customers (Romaniuk et al., 2017). Keller (1993) also agreed that consumers with higher TOMA levels for brands certainly show a higher priority. The nature of the variation of brand awareness over time interacts with a brand's market share. TOMA is specifically more concerned with low engagement purchasing decisions where customers do not seek information about a new brand unless it is above the high awareness of the customer.

Brand Knowledge

Previous researchers stated that brands are undoubtedly worthwhile brand tools. Brand is a multidimensional system that incorporates practical and emotional principles to fulfil customer, performance and behavioral needs (Hassana et al., 2021). One of the aims of branding is to make the brand special in the specific and valued aspects of the consumers. Provided that the brand is a significant factor of every marketing campaign, the definition of its equity must be understood. Therefore, when customers are satisfied and have knowledge about that brand, our brand will come first. This gives service companies the opportunity to increase the retention rate by establishing the brand stock collected by customers. This definition often refers to previous studies (Stocchi et al., 2020). A brand is a known source offering. There are many brand names in the minds of people, most of whom represent the brand image. Every company is determined to create a strong, positive and unique brand image. If a mind doesn't know a brand, the desired brand organizations in consumers are very 
difficult to develop. This researcher, Hassana et al. (2021) mentioned that, the data indicates that consumers who know the brand name are inclined to buy the same brand in subsequent sales, because a well-known brand is often preferred to an unfamiliar one. Brand name buying decisions are very successful in creating brand value (Saadat Nahad, 2011).

\section{Methodology}

The measurement of constructs consists of five (5) sections of questions that are related to the brand awareness, brand recognition, brand recall, top of mind awareness (TOMA), and brand knowledge. The questionnaire was adopted and adapted from Kuthoos et al. (2014); Lehman et al. (2008). This study employed the non-probability sampling, which did not use the chance selection procedures. The respondents who are residents in Melaka. Based on the stated criteria, a total of 300 people were purposely selected and employed as a sample for the current study using a convenient sampling technique. They were assumed to have firsthand knowledge of the subject matter.

The instrument used and item numbers that are in every questionnaire is mentioned in the table below.

Table 1: Research Instruments

\begin{tabular}{|l|l|}
\hline Aspects & Number of Questions \\
\hline Brand awareness & 9 \\
\hline Brand recognition & 7 \\
\hline Brand recall & 10 \\
\hline Top of mind awareness (TOMA) & 6 \\
\hline Brand Knowledge & 9 \\
\hline
\end{tabular}

\section{Findings}

\section{Correlation Analysis}

Table 2 shows the relationship between the variables studied i.e., the relationship between brand recognition, brand recall, Top of Mind Awareness; TOMA, brand knowledge, and brand awareness. The results of this study show that all the independent variables are in a very strong relationship strength according to Albert Davis (1971) table of relationship strength. 
Table 2: Correlation of Variables and Brand Awareness

\begin{tabular}{lll}
\hline Variables & $\boldsymbol{r}$ & $\boldsymbol{p}$ \\
\hline Brand Recognition & $.753^{*}$ & .00 \\
& $*$ & 0 \\
Brand Recall & $.767^{*}$ & .00 \\
& $*$ & 0 \\
Top of Mind Awareness; & $.710^{*}$ & .00 \\
TOMA & $*$ & 0 \\
Brand Knowledge & $.705^{*}$ & .00 \\
& $*$ & 0
\end{tabular}

The results showed that there was a significant positive relationship between brand recognition and brand awareness $(r=0.753, p<0.01)$. Based on the strength of the Albert Davis (1971) relationship, the link between brand recognition and brand awareness is a very strong correlation. The positive correlation indicates that there is a positive relationship that the higher the quality of brand recognition, the higher the level of brand awareness. The findings of this study further support the first hypothesis of the study that brand recognition has a relationship with PUCM brand awareness among the residents in the state of Melaka. There was a significant positive relationship between brand recall and brand awareness supported by a correlation coefficient $(r=0.767, p<0.01)$. Based on the strength of Albert Davis's (1971) relationship, the relationship between brand recall and brand awareness is a very strong correlation. The positive correlation shows that there is a positive correlation that the higher the degree of brand recall, the higher the level of awareness of the PUCM brand among the people of Melaka. The findings of this study further support the second hypothesis, that is, recall the brand has a relationship with PUCM brand awareness among the residents in the state of Melaka.

Similarly, there was a significant relationship between Top-of-Mind Awareness; TOMA and brand awareness with correlation coefficient $(r=0.710, p<0.01)$. Based on the relationship strength of Albert Davis (1971), the value of $r$ indicates that the association between the Topof-Mind Awareness; TOMA and brand awareness is a positive correlation which is also very strong. The results of this study also support the third hypothesis of the study that is Top of Mind Awareness; TOMA has a relationship to PUCM brand awareness among the residents in the state of Melaka.

The results showed that there was a significant positive relationship between brand knowledge and brand awareness $(r=0.705, p<0.01)$. Based on the strength of the Albert Davis (1971) relationship, the correlation between brand knowledge and brand awareness is a very strong correlation. The positive correlation indicates that there is a positive relationship that the higher the level of knowledge about the brand, the higher the level of brand awareness. The findings of this study further support the fifth hypothesis of the study, namely, brand knowledge has a relationship with PUCM brand awareness among the residents in the state of Melaka. 


\section{Multiple Regression Analysis}

Multiple regression analysis was used to test the effect of brand recognition, brand recall, Top of Mind Awareness (TOMA) and brand knowledge, on brand awareness. Regression analysis is a method that allows us to study relationships based on linear equations not only between one variable with one other variable but also between one variable with several variables (Hair et al., 2010).

Table 3: Multiple Regression Analysis

\begin{tabular}{|c|c|c|c|c|c|}
\hline $\begin{array}{l}\text { The dependent } \\
\text { variable }\end{array}$ & Independent variables & $\beta$ & BETA & $\mathrm{t}$ & Sig. \\
\hline & Constant & .594 & & 2.722 & .007 \\
\hline & Brand Recognition $\left(X_{1}\right)$ & .406 & .362 & 3.451 & .001 \\
\hline & Brand Recall $\left(\mathrm{X}_{2}\right)$ & .405 & .378 & 3.568 & .000 \\
\hline \multicolumn{6}{|c|}{ Brand Awareness (Y) } \\
\hline & $\begin{array}{l}\text { Top of Mind Awareness; TOMA } \\
\left(\mathrm{X}_{3}\right)\end{array}$ & .046 & .047 & .395 & .694 \\
\hline & Brand Knowledge $\left(\mathrm{X}_{4}\right)$ & .158 & .157 & 1.387 & .168 \\
\hline $\mathrm{R}^{2}$ & .649 & & & & \\
\hline $\mathrm{F}$ & 43.543 & & & & \\
\hline Sig F & 0.000 & & & & \\
\hline
\end{tabular}

The results of the study shown in Table 3 show that $64.9 \%$ (R2 $=0.649$ ) factors of brand recognition, brand recall, Top of Mind Awareness; TOMA, brand knowledge and influence PUCM brand awareness among residents in Melaka. Table 3 also shows that F-statistics ( $F=$ 43.543 ) and a significant $p$ value (0.000) or smaller than the alpha value of 0.01 . This indicates that the linear regression line slope of this model is estimated not to be equal to zero, confirming that the study data correspond to the six linear regression prediction models proposed in this study.

Referring to the regression analysis, brand awareness $(\mathrm{Y})$ was only influenced by two variables namely brand recognition factor (X1) and brand recall (X2), however Top of Mind Awareness; TOMA (X3) and brand knowledge (X4) had no significant relationship and did not contribute to brand awareness. Based on the results of this study as well, the relationship between brand awareness $(Y)$ influenced by brand recognition factor $(X 1)$ and brand recall $(X 2)$, can be explained using regression analysis expressed through linear equations as follows:

$$
\mathrm{Y}=0.594+0.406\left(\mathrm{X}_{1}\right)+0.405\left(\mathrm{X}_{2}\right)
$$

The results of this study show that if one unit of brand recognition (X1) increases, then the level of brand awareness also increases by 0.406 . Meanwhile one unit of brand recall factor (X2) increased, so the level of brand awareness also increased by 0.405 . While for this study, Top of Mind Awareness; TOMA (X3) and brand knowledge (X4) did not contribute to PUCM brand awareness among the residents of Melaka. The results of this study also support that the factors of brand recognition (X1) and brand recall (X2) most influence the awareness of the PUCM brand among the residents in the state of Melaka.

\section{Discussions}

The first hypothesis, which stated that higher quality of brand recognition and higher level PUCM brand awareness among the people in the state of Melaka the higher the quality of brand. This result is consistent with the results of previous studies conducted by (Chun et al., 2020). This revealed that brand recognition perceived by consumers creates a positive attitude toward PUCM brand awareness. Thus, to increase the brand recognition, PUCM had 
to pay more attention to marketing activities among the residents in the state of Melaka to enhance brand awareness.

Next, the second hypothesis stated higher the degree of brand recall, the higher the level of awareness of the PUCM brand among the residents in Melaka. The findings of this study further support the second hypothesis, that is, recall the brand has a relationship with PUCM brand awareness among the residents in the state of Melaka. This result is in accordance with the previous studies Havale \& Chaudhari (2020); Lu, Chang \& Chang, (2014); Ndlela \& Chuchu, (2016); Schmidt \& Eisend (2015) the brand is remembered and recalled highly if it is appearing for a greater number of times. Thus, for the brand recall effect, more levels of exposure are required. Therefore, PUCM has to ensure that advertising needs to be strengthened and mass exposure increases the impact of repetition on Brand Recall.

In addition, the third hypothesis, which stated that the higher of TOMA, means that the higher it has a relationship to PUCM brand awareness among the residents in the state of Melaka. This result is in line with the studies by Keller (1993); Romaniuk et al 12017); Varintrasirisuthikul (2017) higher TOMA levels for brands certainly show a higher priority for brand awareness for PUCM. Top of Mind Awareness (TOMA) indicates whether a brand is recalled without any memory aid. The most important reminder is more challenging because it is actually a behavioral tendency. Therefore, the management must innovate to increase TOMA among the residents in Melaka through various marketing tools.

\section{Conclusion}

Conclude that PUCM brand awareness has an important impact in ensuring sustainability in the field of education and the problems faced by PUCM, declining student enrolment in recent years. This indicates that the elements of brand awareness enhance and strengthen the PUCM brand and further increase the number of student admissions. This research focused on a few elements of brand awareness to strengthen the PUCM brand such as brand recognition, recall, top of mind awareness and knowledge. From these elements we identified that brand recognition and brand recall were the most influences towards PUCM brand awareness. Therefore, it is important for PUCM to maintain their brand name to attract stakeholders such as prospective students and alumni in their assessments, which has an impact on choice of whether to study, to collaborate and to extend assistance or contributions to the university. In the future research, researchers include all elements of brand awareness which is brand dominance and brand opinion will provide more valid research outcome.

Brand awareness becomes a crucial issue when the world grows with advanced technology in this 21st century. Many higher education institutions including PUCM find opportunities to upgrade their brand among the communities to sustain. This research outcome showed that factors that strongly influenced PUCM brand awareness among the residents in Melaka are brand recognition and brand recall. Hypothesis testing analysis all reject $\mathrm{H}$ null means that all the independent variables (IV) have relationship towards PUCM brand awareness among the residents in Melaka and respondent's agreed and strongly agreed that brand awareness is important to highlight in order to be competitive advantage. Additionally, nowadays many organizations including PUCM are trying harder in order to build the brand internally and maintain it. This shows that PUCM need to maintain their product image and increase familiarity in order to develop trust with their product and company. Besides, it will be necessary for PUCM to increase the advertising in different levels of exposure to strengthen their brand recall. Lastly the limitation of this research is lack of in-depth sample population 
and findings regarding faces covid 19 situation which is this research only focus in Melaka. In addition, it's good for further research in future.

\section{Acknowledgement}

This researcher would like to thank the Kolej Universiti Islam Melaka, for the opportunity given run this study.

\section{Corresponding Author}

Maryam Mohd Esa

Kolej Universiti Islam Melaka Malaysia

Email: maryam@kuim.edu.my

\section{References}

Biscaia, R., Correia, A., Ross, S., \& Rosado, A. (2014). Sponsorship effectiveness in professional sport: an examination of recall and recognition among football fans. International Journal of Sports Marketing and Sponsorship, 16(1), 2-18.

Chen, L. S., \& Tsai, Y. C. (2016). Exploring the relationships among college brand reputation, interaction between service personnel and students, brand identification, brand loyalty, satisfactory experience sharing and recommendation: A case study of Yuan Ze University. Journal of Recreation Sport and Health Promotion, 11, 25-46.

Chen, C. T. (2019). The mediating effect of brand identity on brand knowledge and the operational development of universities. South African Journal of Business Management, 50(1), 1-11.

Chun, T. Y., Lee, D. K., \& Park, N. H. (2020). The Effect of Marketing Activities on the Brand Recognition, Brand Familiarity, and Purchase Intention on the SNS of Franchise Companies. The Journal of Asian Finance, Economics and Business, 7(11), 955-966. https://doi.org/10.13106/jafeb.2020.vol7.no11.955

Gijsenberg, M. J., \& Nijs, V. R. (2018). Advertising spending patterns and competitor impact. International Journal of Research in Marketing, xxxx.

https://doi.org/10.1016/j.ijresmar.2018.11.004

Gupta, P. B. (1998). Product placement in movies: The effect of prominence and mode on audience recall. Journal of Current Issues and Research in Advertising, 20(1), 47-59.

Hassana, M., Zakaib, S. N., Azeem, M., Qureshic, D., Bashird, M. A., Sufyan, M., Hassan, M. \& Udding, I. (2021). Descriptive Dimensions of Brand Equity in the Insurance Industry of Pakistan: A Literature Review. International Journal of Innovation, Creativity and Change. Volume 15, Issue 4, 2021

Havale, M. D. S., \& Chaudhari, D. C. (2020). Critical Study of Branding in films: Correlation of Brand Promotion, Brand Awareness, Brand Usage, and Brand Recall with Consumer Buying Intentions. Gedrag \& Organisatie Review, 33(02). https://doi.org/10.37896/gor33.02/140

Huang, R., \& Sarigöllü, E. (2014). How brand awareness relates to market outcome, brand equity, and the marketing mix. In Fashion branding and consumer behaviors (pp. 113132). Springer, New York, NY.

Ilyas, G. B., Rahmi, S., Tamsah, H., \& Munir, A. R. (2020). Reflective model of brand awareness on repurchases intention and customer satisfaction. The Journal of Asian Finance, Economics, and Business, 7(9), 427-438.

Keller, K. L. (1993). Conceptualizing, measuring, and managing customer-based brand 
equity. Journal of marketing, 57(1), 1-22.

Kuthoos, H. M. B. A., Noor, S. M., Hashim, N. H., \& Siarap, K. (2014). Pembinaan metriks ekuiti jenama universiti. Jurnal Komunikasi: Malaysian Journal of Communication, 30(1).

Lehmann, D. R., Keller K. L., Farley, J. U. (2008). "The Structure of Survey -Based Brand Metrics". Journal of International Marketing, Vol 16. No 4, pp.29-56

Lu, L. C., Chang, W. P., \& Chang, H. H. (2014). Consumer attitudes toward blogger 's sponsored recommendations and purchase intention: The effect of sponsorship type, product type, and brand awareness. Computers in Human Behavior, 34, 258-266.

Malik, M. E., Ghafoor, M. M., Hafiz, K. I., Riaz, U., Hassan, N. U., Mustafa, M., \& Shahbaz, S. (2013). Importance of brand awareness and brand loyalty in assessing purchase intentions of consumer. International Journal of business and social science, 4(5).

Ndlela, T., \& Chuchu, T. (2016). Celebrity endorsement Advertising: Brand awareness, brand recall, brand loyalty as antecedence of South African young consumers' purchase behaviour. Journal of Economics and Behavioral Studies, 8(2 (J)), 79-90.

Netemeyer, R. G., Krishan, B., Chris, P., Wang, G., Yagci, M., Dean, D., Ricks, J. and Wirdh, F.(2004), "Developing and validating measure of facets of customer-based brand equity", Journal of Business Research, Vol. 57 No. 1, pp. 209-224

Noorlitaria, A., Pangestu, F. R., Surapati, U., \& Mahsyar, S. (2020). HOW DOES BRAND AWARENESS AFFECT PURCHASE INTENTION IN MEDIATION BY PERCEIVED QUALITY AND BRAND LOYALTY? Journal of Critical Reviews, 7(2), 103-109.

Permana, A. W. (2021). The Influence of social media, Brand Awareness, Brand Image, Brand Experience Through Satisfaction and Trust on Purchase Decisions During The COVID-19 Pandemic. 4(01), 7-15.

Prashar, B., Dahir, S., and Sharma, A. (2012). Study of brand recall of consumer durables among consumers in Punjab. International Journal of Research in Commerce, IT and Mgmt., 2(7), 84-88.

Romaniuk, J., Wight, S., \& Faulkner, M. (2017). Brand awareness: revisiting an old metric for a new world. Journal of Product \& Brand Management.

Nahad, S. M. H. (2011). The impact of marketing mix on dimensions of brand equity; Alborz Institute of Higher Education; Graduate Faculty (Doctoral dissertation, MA thesis of marketing executive management).

Schmidt, S., \& Eisend, M. (2015). Advertising repetition: A meta-analysis on effective frequency in advertising. Journal of Advertising, 44(4), 415-428.

Stocchi, L., Ludwichowska, G., Fuller, R., \& Gregoric, A. (2020). Customer-based brand equity for branded apps: A simple research framework. Journal of Marketing Communications, 1-30.

Varintrasirisuthikul. (2017). Examination of brand perception and brand awareness of undergraduate and graduate students towards sustainability. International Journal of Management and Applied Science, Issn: 2394-7926 Volume-3, Issue-11, Nov.-2017. 82.

Zia, A., Younus, S., \& Mirza, F. (2021). Investigating the Impact of Brand Image and Brand Loyalty on Brand Equity: The Mediating Role of Brand Awareness. International Journal of Innovation, Creativity and Change, 15(2), 1091-1106. Books

Aaker, D. A. (2004). Brand portfolio strategy. New York, NY: Free Press.

Keller, K. (2001). Strategic Management Building, Customer- Based Brand Equity. Marketing Management, Harlow, United Kingdom, Pearson Education Limited.

Keller, K. (2008). Strategic Brand Management-Building, Measuring, and Managing Brand Equity. Upper Saddle River, NJ: Prentice Hall. 
Keller, K. L. (2001). Building customer-based brand equity: A blueprint for creating strong brands (pp. 3-27). Cambridge, MA: Marketing Science Institute.

Kotler, P. (2000), Marketing Management. The Millennium Edition, Upper Saddle River, Prentice Hall. 